expenditure for expansion and increased productivity over the next five years of $£ 2,000$ million, the Post Office says that charges must be brought into line with costs. The position is being reviewed by the Prices and Incomes Board.

The telecommunications section is aiming to increase the size of the system by 50 per cent without increasing overall manpower, by using more machinery. Improvement of service for the existing 7.7 million subseribers will be the most important task in the coming year, and a net increase of half a million subscribers is expected. The various local, trunk and overseas lines are all being increased, as are exchanges and the number of telex lines. By March 1969 it is expected that 98 per cent of customers will be on automatic exchanges. Automation is progressing in such fields as international telex and telegrams; data transmission services are being expanded, and additional submarine cable links with various European countries are being laid. Aluminium conductors have been successfully used instead of copper in telephone cables, and further use of aluminium is expected to benefit the economy because of the high price of imported copper.

The postal section will see two important developments in the coming year-the two-tier post system in the autumn with lowest rates of postage being open only to mail in "post office preferred" envelopes, and the inauguration of the National Giro Service at its Lancashire headquarters. Modern techniques of management and marketing are being examined for staff and stamps, respectively, and post codes will be allocated to parts of London and twenty-five other towns and cities. During the year, twenty mechanized sorting offices will be brought into service.

\section{New Units for Industry}

The process of changing all Britain's units from the old imperial system to the metric system is a messy business. Colonel J. S. Vickers, chairman of the Planning Group of the British Standards Institution, which is planning the change, calls it "an agony". But at least everyone agrees that the medicine, once taken, will do the patient good. The arguments are about who should take the medicine first. In most countries which have made the change, the retail trade, which includes packaging, has adopted the new units first, but in Britain the opposite will happen. The plans for the retail trade will depend on the recommendations of the Joint Committee on Metrication, a Ministry of Technology body whose chairman is Mr Arthur Wynne. The committee is widely expected to accept a recommendation made to it by the CBI (see Nature, 216, 1157; 1967) and propose the formation of a Metrication Board.

Last week the BSI was able to announce its plans for the engineering industry. After consultation with industry which seems to have been somewhat onesided (of 1,600 firms to which the BST sent its original questionnaire, only 250 replied), the BSI has prepared a draft programme which it is circulating to industry through trade associations. The period of transition has been set at 1970-75. The terminal date was fixed by a Board of Trade decree, so all that really needed deciding was the starting date. 1970 seems to have been the overwhelming favourite. The first industry to go metric, chosen because its problems were likely to be the greatest, will be the engineering equipment manufacturers, who use the basic engineering materials to produce equipment which is then used by the process industries. This time-scale will, the BSI says, fit in with the plans of the construction industry, which is on the way to metrication already. Some 20,000 copies of the draft programme have been sent to engineering companies through their trade associations, and they have been invited to send comments to the BSI by March 29. Companies not members of any trade association can get copies from the BSI.

\section{Another New Reactor}

Despite its great cost, which might be expected to dictate caution, nuclear reactor design remains astonishingly diverse. Almost every conceivable combination of coolant, moderator and fuel has been studied, on paper if not in actual hardware, although. most of these systems are unlikely to evolve into commercial power reactors. Although Britain has so far tended to favour gas cooling for thermal reactors, the United Kingdom Atomic Energy Authority last week invited the Duke of Edinburgh down to Winfrith to open its latest reactor, which is water cooled. In the event, the considerable skill of the authority at public relations had to be directed at those who thought the royal visit had cost a great deal too much, but the virtues of the reactor were not entirely forgotten. It had, after all, cost $£ 16$ million itself.

The reactor is called, somewhat inelegantly, the steam generating heavy water reactor, abbreviated to SGHWR. It is a system in which moderation by heavy water is combined with cooling by ordinary water, which boils and drives the turbine generators in a direct cycle. The design uses a number of pressure tubes, rather than a single pressure vessel, an arrangement with several important advantages. The fuel, slightly enriched uranium dioxide, is contained in thin tubes made of zirconium alloy; 36 such tubes go to make up each fuel element. Cooling water passes up the tubes, which are surrounded by an aluminium calandria (vessel) containing heavy water moderator.

The electrical output of the station is $100 \mathrm{MW}$, which is fed into the National Grid. The reactor can be refuelled either on-load or off-load, although the advantages of on-load refuelling seem much overrated. If the reactor is refuelled off-load, the whole job can be done in a weekend so that most customers are likely to choose this option. The pressure tube design allows much of the fabrication work to be done in the workshop instead of on-site, which is a valuable advantage in places where welding technology is less advanced than it is in the United States. The authority is tentative about quoting costs, but says that capital costs should work out at about $£ 60$ per kilowatt, with generating costs of 0.50 pence a $\mathrm{kWh}$ or less. The reactor is a good plutonium producer, very much better than the advanced gas cooled reactor, and about the same as a boiling water reactor. The design can also be adapted for natural, rather than enriched uranium. The authority says that there would be no difficulty in building an SGHWR as big as 1,000 MW.

So far, however, the whole contracting position is a mystery. The authority firmly says that "the team which built this reactor will take on contracts anywhere". Under these circumstances, the AEA would 